\title{
Ecological aspects of small strongylids in the Paraíba Valley Region, State of São Paulo, Brazil
}

\author{
Aspectos ecológicos dos pequenos estrongilídeos na região do Vale do Paraíba, Estado de São Paulo, \\ Brasil
}

\author{
José Roberto Pereira ${ }^{\mathrm{I}^{*}}$ Sérgio Sebastião da Silva Vianna ${ }^{\mathrm{I}}$
}

\begin{abstract}
Post-mortem studies were conducted on twenty equids (16 horses and four mules) of the Paraíba Valley, during a period of twelve years (1988 to 2000) in order to establish the ecological descriptors of the different species of small strongylids (Subfamily Cyathostominae, Tribe Cyathostominea). Samples of $10 \%$ of total gastrointestinal content was examined and a total of 13,832 of Cyathostominea were obtained with a prevalence of $100 \%$. The most prevalent and abundant species were Cylicocyclus nassatus (100\%), Cylicostephanus longibursatus and Cylicostephanus goldi (95\%). The population of Cyathotominea showed an average Dispersion Index (DI) of 49.03 and an average Green index (GI) of 0.226. The parasitic community had average diversity of 1.79, calculated by Shannon-Wiener' Index, and 0.77 by Simpson's Index of Diversity. The evenness (Pielou's Index) presented an average of 0.28 . The intensity of infection had a positive correlation with the parasite richness $(P<0,05)$ and the diversity $(P<0,01)$. Specimens of $C$. nassatus showed preference for the ventral colon $(P<0.01)$, Cyathostomum coronatus for the caecum $(P<0.01)$, C. longibursatus and $C$. goldi a preference for both the ventral colon and the dorsal colon $(P<0.01)$.
\end{abstract}

Key words: equids, Cyathostominae, ecology, São Paulo, Brasil.

\section{RESUMO}

Foram realizados estudos post-mortem em 20 eqüídeos provenientes do Vale do Paraíba para obtenção de descritores ecológicos dos pequenos estrongilídeos (Subfamíia, Cyathostominae, Tribo Cyathostominea). Das alíquotas de 10\% do conteúdo intestinal total, foram recuperados 13.832 Cyathostominea com $100 \%$ de prevalência. As espécies, Cylicocyclus. nassatus (100\%), Cylicostephanus Iongibursatus e Cylicostephanus goldi (95\%) foram as mais prevalentes $e$ abundantes. A população de Cyathostominea apresentou Índice de Dispersão (ID) médio de 49,03 e Índice de Green (IG) médio de 0,226. A diversidade apresentou média de 1,79 (İndice de Shannon - Wiener) e 0,77 (Índice de Diversidade de Simpson). $O$ índice de Pielou registrou equitabilidade média de 0,28. A intensidade da infecção apresentou correlação positiva com a riqueza parasitária $(P<0,05)$ e a diversidade $(P<0,01)$. Espécies de C. nassatus mostraram preferência pelo cólon ventral $(P<0,01)$, Cyathostomum coronatus pelo ceco $(P<0,01)$, C. longibursatus e C. goldi preferência por ambos, cólon ventral e cólon dorsal $(P<0,01)$.

Palavras-chave: eqüídeos, Cyathostominae, ecologia, São Paulo, Brasil.

\section{INTRODUCTION}

Of all the gastrointestinal helminths that parasitise equids, the Cyathostominea, also known as small strongylids, present the biggest problem to their hosts. The Cyathostominea cause both clinical and subclinical disease. Clinical disease known as Cyathostomosis occurs when large numbers of encysted or hypobiotic larval re-emerge in the intestinal lumen. Symptoms of acute diarrhoea soon become chronic and weight loss, colic, subcutaneous oedema are seen (MAIR et al., 1994). This can be fatal in some cases (VAN LOON et al., 1995). The situation is worsened by the inefficiency of the anthelmintics like the avermectins which at the prescribed dose and even at 5 times the recommended dose do not have a

'Agência Paulista de Tecnologia dos Agronegócios (APTA), Polo Regional de Desenvolvimento Tecnológico dos Agronegócios. Av. Prof. Manoel César Ribeiro, 320, 12411-010, Pindamonhangaba, SP, Brasil. E-mail: jroberto@apta.sp.gov.br. *Autor para correspondência. 
significant effect against the encysted or hypobiotic larvae of these parasites (HERD \& COLLES, 1995).

In Brazil, several investigative studies on prevalence and abundance regarding the Cyathostominae have already been published (LANFREDI, 1983; BARBOSA, 1995; OLIVEIRA et al., 1994; CARVALHO etal., 1998; SILVA et al., 1999; SOUTO MAIOR et al., 1999; RODRIGUES et al., 2000; ANJOS \& RODRIGUES, 2006). However, only studies conducted in Rio de Janeiro (SOUTO MAIOR et al., 1999; RODRIGUES et al., 2000; ANJOS \& RODRIGUES, 2006), considered the ecological analysis of the communities of equine parasites in the segments of the large intestine (caecum, ventral colon and dorsal colon) in individualised fashion.

Studies conducted in the Paraíba Valley in São Paulo have recorded a high prevalence (100\%) of these parasites in equids in this region (PEREIRA \& VIANNA, 2006). Thus, the main aim of the present study was to provide, as well as the usual data of prevalence and abundance, ecological descriptors of the Cyathostominea that parasitise equids in the Paraíba Valley Region. This data is of paramount importance for the adoption of effective measures for the control of these parasites, given that we have seen the appearance of new species within the Cyathostominea population that are resistant to anthelminthics (NILSSON et al., 1989; BORGSTEEDE et al., 1997).

\section{MATERIAL AND METHODS}

Between 1988 and 2000, twenty naturally infected equids, 16 horses and four mules, were subjected to necropsy and their gastrointestinal parasites identified. All animals in the study came from the Paraíba Valley Region. Comprehensive data about characteristics of the region, sanity, age brackets and regional origin of the animals can be found in PEREIRA \& VIANNA (2006). On necropsy the animals had the large intestine removed and the various compartments (caecum, ventral and dorsal colon) were isolated and then opened, their contents were placed in a bucket. The organs were then washed and scraped into separate buckets. The floating content of the latter washings were then decanted. The sediment added to the bucket containing the total contents for each organ and $10 \%$ samples of each of these buckets were taken and homogenised, and then kept in formaldehyde (10\%) at $60^{\circ} \mathrm{C}$. Helminths were collected with the aid of a stereoscopic microscope, stored in a small jar containing formaldehyde and then identified through optic microscopy LICHTENFELS (1975), GEORGI
(1982) and LICHTENFELS et al. (1998), temporarily mounted between slide and microslide after clearance in a $80 \%$ phenol solution in alcohol (LICHTENFELS, 1975).

The parasitic ecology concepts and terms used are those proposed by MARGOLIS et al. (1982) and BUSH et al. (1997). Data were obtained with regard to the male/female ratio, ecological descriptors, as Dispersion Index, the Green Index, the Shannon Index, and the Pielou Uniformity Index (LUDWIG \& REYNOLDS, 1988) and Simpson's Index of Diversity (RODRIGUES, 2008).

The data regarding the worm count was transformed into $\operatorname{Ln}(\mathrm{x}+1)$ and the correlations between the intensity of the infection and the Shannon' Index and Simpson' Index; intensity of the infection and parasite richness were analysed using the Pearson Correlation Test.

To establish the favourite site for each species, the intensities have been compared in each region of occurrence (caecum, ventral colon and dorsal colon), using analysis of variance and also using the Student $t$ test. In these calculations, use has been made only of data arising from species that have been present in at least ten equids (COLOBERT-LAUGIER et al., 2002).

\section{RESULTS}

The total population of helminth collected in the digestive tract of equids and their prevalence and abundance were detailed in PEREIRA \& VIANNA (2006). The present publication has limited its coverage to the species of tribe Cyathosthominea. These parasites were present in all the equids examined. A total of 13,832 helminths were found. Eight genera and 23 species were represented, with a prevalence of $100 \%$ and abundance of 691.60 helminths/animal examined (Table 1). In this study, the immature forms (larvae) have not been considered.

The most prevalent (100\%) and abundant species (128.70 individuals/animal studied) was $\boldsymbol{C}$. nassatus and the least prevalent (10\%) Cylicocyclus elongatus (Table 1). The average proportion between the number of males and females collected was 1:2.01. Samples of $\boldsymbol{C}$. nassatus showed the lowest proportion (1:0.65). The population of Cyathostominea showed a distribution standard of clustered distribution (Variance > Mean) with DI between 1.52 and 162.94, but with a low clustering index (a mean GI of 0.226), according to table 2 .

The community had parasitic diversity media of 1.79, calculated by the Shannon- Wiener' Index, and 
Table 1 - Quantitative descriptors of parasite populations of Cyathostominea collected from naturally infected equids (n=20) in the Paraíba Valley Region, State of São Paulo, Brazil (Sample of 10\% of gastrointestinal contents).

\begin{tabular}{lcccc}
\hline Species & Prevalence (\%) & Ratio specie/total helminths (\%) & Intensity range & Relative abundance \\
\hline Coronocyclus coronatus & 90 & 5.99 & $1-192$ & 41.45 \\
C. labiatus & 50 & 0.79 & $1-26$ & 5.45 \\
C. labratus & 30 & 0.38 & $1-15$ & 2.60 \\
Cyathostomum catinatum & 90 & 13.64 & $8-286$ & 94.35 \\
C. pateratum & 80 & 6.22 & $1-286$ & 43.00 \\
Cylicocyclus ashworti & 80 & 4.87 & $1-168$ & 33.65 \\
C. brevicapsulatus & 40 & 0.10 & $1-3$ & 0.70 \\
C. elongatus & 10 & 0.09 & $1-12$ & 0.65 \\
C. insigne & 45 & 3.77 & $1-290$ & 26.05 \\
C. leptostomum & 60 & 1.42 & $1-68$ & 9.80 \\
C. nassatus & 100 & 18.61 & $4-384$ & 128.70 \\
C. radiatus & 20 & 0.33 & $1-30$ & 2.30 \\
C. ultrajectinus & 25 & 0.47 & $1-192$ & 3.25 \\
Cylicodontophorus bicoronatus & 65 & 1.23 & $1-40$ & 8.50 \\
Parapoteriostomum euproctus & 60 & 0.82 & $1-26$ & 5.70 \\
P. mettami & 20 & 0.07 & $1-5$ & 0.45 \\
Petrovinema poculatum & 35 & 0.12 & $1-4$ & 0.80 \\
Cylicostephanus minutus & 90 & 2.67 & $1-76$ & 18.45 \\
C. calicatus & 80 & 4.90 & $2-182$ & 33.90 \\
C. longibursatus & 95 & 16.92 & $8-378$ & 117.05 \\
C. goldi & 95 & 16.36 & $8-319$ & 113.15 \\
Poteriostomum ratzii & 25 & 0.11 & $1-11$ & 0.75 \\
Poteriostomum imparidentatum & 25 & 0.13 & $1-5$ & 0.90 \\
Total & & & & 691.60 \\
\hline
\end{tabular}

0.77 by Simpson's Index of Diversity. The intensity of infection had a positive correlation with the parasite richness ( $\mathrm{r}=0.5460, \mathrm{P}<0.05)$ and the diversity, both by the Shannon-Wiener' Index $(\mathrm{r}=0.6421, \mathrm{P}<0.01)$ as Simpson'Index $(r=0.7577, \mathrm{P}<0.01)$. The evenness (Pielou' Index) presented similar between communities, ranging from 0.21 to 0.34 with an average of 0.28 (Table 3 ). Most speciments recovered were on the ventral colon (57.4\%), followed by the dorsal colon (29.6\%) and caecum (15.7\%). Out of all the compartments (Table 4), C. nassatus showed preference for the ventral colon $(\mathrm{P}<0.01)$ and $\boldsymbol{C}$. coronatus for the caecum $(\mathrm{P}<0.01)$. In the cases of $\boldsymbol{C}$. longibursatus and C. goldi there seemed to be a joint preference for the ventral and the dorsal colon $(\mathrm{P}<0.01)$, without any statistically significant difference in these compartments.

\section{DISCUSSION}

The above results confirm previously studies about the Cyathostominea and the wide prevalence and abundance of these parasites in equids. Out of the 52 currently recognised species of Cyathostominea that parasitise equids (LICHTENFELS et al., 2002), 23 were found in this study. Previous studies conducted in the region by VIANNA et al. (1988) and VIANNA \& ARAÚJO (1989) identified 24 and 21 species of small strongylids parasites, in horses and mules. No reference is made to the prevalence and abundance of these parasites.

The high prevalence and abundance of the species $\boldsymbol{C}$. nassatus found in this study is in agreement with the results found by other studies in Brazil (LANFREDI, 1983; OLIVEIRA et al., 1994; BARBOSA, 1995; CARVALHO et al., 1998; SILVA et al., 1999). Apart from $\boldsymbol{C}$. nassatus, species such as $\boldsymbol{C}$. longibursatus and $C$. goldi and Cyathostomum catinatum, Cylicostephanus minutus and $\boldsymbol{C}$. coronatus have a higher prevalence and abundance in equids. The high incidence of these species is in line with the findings of other studies undertaken in this country (LANFREDI, 1983; OLIVEIRA et al., 1994; BARBOSA, 1995; CARVALHO et al., 1998; SILVA et al., 1999). The population of these species accounted for $75 \%$ of the Cyathostominea observed, confirming a feature of this group, where a large number of species coexist on one same host, with a predominance of several individuals of a few species (OUGBOURNE, 1976).

The low prevalence of $\boldsymbol{C}$. elongatus in the animals of this region agrees with the findings of other 
Table 2 - Aggregation indexes of Cyathostominea collected from naturally infected equids $(n=20)$ in the Paraíba Valley region, State of São Paulo, Brazil (Sample of 10\% of gastrointestinal contents). Dispersion Index (DI) and Green’s Index (GI).

\begin{tabular}{lll}
\hline Species & DI & GI \\
\hline Coronocyclus coronatus & 61.45 & 0.07 \\
C. labiatus & 14.38 & 0.12 \\
C. labratus & 9.49 & 0.17 \\
Cyathostomum catinatum & 115.55 & 0.06 \\
C. pateratum & 133.23 & 0.15 \\
Cylicocyclus ashworti & 85.15 & 0.13 \\
C. brevicapsulatus & 1.52 & 0.04 \\
C. elongatus & 14.03 & 0.87 \\
C. insigne & 162.94 & 0.31 \\
C. leptostomum & 28.53 & 0.31 \\
C. nassatus & 92.56 & 0.14 \\
C. radiatus & 22.70 & 0.04 \\
C. ultrajectinus & 41.58 & 0.48 \\
Cylicodontophorus bicoronatus & 21.01 & 0.63 \\
Parapoteriostomum euproctus & 9.09 & 0.12 \\
P. mettami & 3.15 & 0.07 \\
Petrovinema poculatum & 2.32 & 0.27 \\
Cylicostephanus minutus & 34.37 & 0.09 \\
C. calicatus & 73.06 & 0.09 \\
C. longibursatus & 97.23 & 0.11 \\
C. goldi & 89.50 & 0.04 \\
Poteriostomum ratzii & 7.98 & 0.50 \\
Poteriostomum imparidentatum & 3.85 & 0.17 \\
Mean & 49.03 & 0.23 \\
Standart Deviation & 47.75 & 0.29 \\
\hline & &
\end{tabular}

studies carried out in Brazil (LANFREDI, 1983, OLIVEIRA et al., 1994; SOUTO MAIOR et al., 1999), despite the species being described as common by LICHTENFELS (1975).

The average proportion observed between the numbers of males and females $(1: 2.01)$ was in agreement with the findings reported by BARBOSA (1995), CARVALHO et al. (1998), SILVAet al. (1999) and ANJOS \& RODRIGUES, 2006. However, we must mention the low ration which this study found in the case of $\boldsymbol{C}$. nassatus (1:0.65) or even in the works of some of the authors previously mentioned. As the species has always been reported as more prevalent and abundant, the lower number of females is probably not associated to this indicator. This relation can be seen for Petrovinema poculatum, a species with low prevalence and abundance, for which we observed a low ratio (1:0.60), as, indeed, have other authors, including CARVALHO et al., (1998) (1:0.50), SILVA et al., 1999 (1:0.54) and BARBOSA, 1995, this latter study finding no females in 148 identified individuals.
The standard distribution clustering we have found, also found in other studies that have been concerned with the observation of this data, seems to be a rule for helmintths on equids (SOUTO MAIOR et al., 1999; RODRIGUES et al., 2000; ANJOS \& RODRIGUES, 2006), which, according to SHAW \& DOBSON (1995), is a standard feature of parasites. The Dispersion Index in terms of measuring the extent of clustering is not commonly used, as it is influenced by the number of individuals in the sample. The Green Index, apart from not being very dependent on the size of the sample, also estimates the dimensions of the clustering, on a scale from 0 (random distribution) to 1 (maximum clustering, should all the individuals be obtained from one same sample), according to JAYARAMAN (2008). Thus, in this case, the mean GI obtained, at 0.226 , means a relatively low clustering standard for the population of Cyathostominea. The diversity is due to the richness of species (the number of species that live in a given habitat) and intensity of infection (size of populations). The Shannon-Wiener Index ( $\left.\mathrm{H}^{\prime}\right)$ gives greater weight to rarer species, while the Simpson Index (E) prefers the common species (BUSH et al. 1997). We obtained an average H' of 1.79, while the Simpson Index mean of 0.77, a value which suggests a high degree of diversity, as this index considers an interval between 0 and 1, as minimum and maximum diversity respectively. The Shannon' Index is adimensional.

The intensity of infection with Cyathostominea in equids shows positive correlation $(\mathrm{P}<0.05)$ with the richness and the diversity of the species recovered $(\mathrm{P}<0.01)$, regardless of the index used for the calculation of the index (Shannon or Simpson), this being a fact which has also been confirmed by COLLOBERT-LAUGIER(2002) in France.

Equitability shows the way in which the number of individuals is distributed among different species. In our study, the mean was 0.28 , suggesting low equitability, as the index considers the interval between 0 and 1 , with 1 being the maximum value for uniformity (if all species have the same abundance).

There are no parameters in relevant literature about clustering, diversity and equitability specifically for Cyathostominea, within the total content of the large intestine in equids, and the observations that exist refer to individualised compartments.

Similar to our results and those of other publications, the dorsal colon and the ventral colon were preferred by most species (Le ROUX, 1924; FOSTER, 1936; FOSTER \& ORTIZ, 1937; OGBOURNE, 1976; RODRIGUES et al., 2000; ANJOS \& RODRIGUES, 2006). The preference of $\boldsymbol{C}$. nassatus $(\mathrm{P}<0.01)$ for the 
Table 3 - Quantitative descriptors of parasites communities of Cyathostominea collected from naturally infected equids (n=20) in the Paraíba Valley Region, State of São Paulo, Brazil (Sample of 10\% of gastrointestinal contents). Pearson’s Correlation Coefficient (r).

\begin{tabular}{|c|c|c|c|c|c|}
\hline Animals & Intensity of infeccion & Species richness & Simpson's Index (E) & Shannon's Index (H') & Pielou's Index (J') \\
\hline 01 & 1049 & 15 & 0.82 & 1.94 & 0.28 \\
\hline 02 & 1083 & 18 & 0.81 & 2.00 & 0.29 \\
\hline 03 & 1015 & 13 & 0.82 & 1.93 & 0.28 \\
\hline 04 & 1121 & 17 & 0.81 & 1.82 & 0.26 \\
\hline 05 & 982 & 8 & 0.74 & 1.47 & 0.21 \\
\hline 06 & 1089 & 15 & 0.81 & 1.92 & 0.28 \\
\hline 07 & 1061 & 14 & 0.85 & 2.02 & 0.29 \\
\hline 08 & 869 & 14 & 0.78 & 1.77 & 0.26 \\
\hline 09 & 72 & 6 & 0.44 & 0.89 & 0.21 \\
\hline 10 & 1063 & 8 & 0.78 & 1.64 & 0.24 \\
\hline 11 & 484 & 12 & 0.77 & 1.73 & 0.28 \\
\hline 12 & 582 & 17 & 0.86 & 2.18 & 0.34 \\
\hline 13 & 415 & 11 & 0.84 & 1.99 & 0.33 \\
\hline 14 & 120 & 10 & 0.70 & 1.57 & 0.34 \\
\hline 15 & 714 & 16 & 0.78 & 1.96 & 0.30 \\
\hline 16 & 269 & 10 & 0.62 & 1.28 & 0.23 \\
\hline 17 & 495 & 18 & 0.82 & 1.99 & 0.32 \\
\hline 18 & 248 & 12 & 0.76 & 1.75 & 0.32 \\
\hline 19 & 423 & 12 & 0.75 & 1.73 & 0.29 \\
\hline 20 & 678 & 18 & 0.85 & 2.19 & 0.34 \\
\hline Mean & 691.60 & 13.202 & 0.77 & 1.79 & 0.28 \\
\hline Standard Deviationn & 358.88 & 3.6 & 0.10 & 0.31 & 0.04 \\
\hline
\end{tabular}

Correlation between Intensity of infecction and Shannon' Index $(\mathrm{r}=0.6421, \mathrm{P}<0.01)$.

Correlation between Intensity of infecction and Simpson'Iindex $(r=0.7577, P<0.01)$.

Correlation between Intensity of infecction and Species richness $(r=0.5460, \mathrm{P}<0.05)$.

ventral colon is in conformity with other publications, like those of FOSTER (1936), FOSTER \& ORTIZ (1937), OGBOURNE(1976), COLLOBERT-LAUGIER(2002)and ANJOS \& RODRIGUES (2006). The double preference $(\mathrm{P}<0.01)$ shown by $\boldsymbol{C}$. longibursatus and $\boldsymbol{C}$. goldi for the ventral colon and the dorsal colon only disagrees with the findings of Le ROUX (1924), the only author to mention $\boldsymbol{C}$. goldi as the species common in the caecum, a compartment where we have not found any examples of this parasite. The significant preference of C. coronatus for the caecum $(\mathrm{P}<0.01)$ is a result which is unanimous among the authors who have been consulted. Even though most species of Cyathostominea show significant preference for a

Table 4 - Location in large intestine of Cyathostominea (species which were identified at least 10 horses - arithmetic mean) collected from naturally infected equids in the Paraíba Valley Region, State of São Paulo, Brazil (Sample of $10 \%$ of gastrointestinal contents). Student's $t$ - test.

\begin{tabular}{|c|c|c|c|}
\hline Species & Ventral colon & Dorsal colon & Caecum \\
\hline Cylicocyclus nassatus & $163.00^{\mathrm{a}^{*} \mathrm{~A}^{* *}}$ & $18.20^{\mathrm{b} A B}$ & $6.80^{\mathrm{bB}}$ \\
\hline Cylicostephanus longibursatus & $54.67^{\mathrm{aA}}$ & $53.60^{\mathrm{aA}}$ & $0.27^{\mathrm{b} \mathrm{B}}$ \\
\hline Cylicostephanus goldi & $59.87^{\mathrm{a} \mathrm{A}}$ & $48.60^{\mathrm{aA}}$ & $0.00^{\mathrm{bB}}$ \\
\hline Cyathostomum catinatum & $55.73^{\mathrm{aA}}$ & $8.67^{\mathrm{bB}}$ & $13.40^{\mathrm{bB}}$ \\
\hline Coronocyclus coronatus & $2.79^{\mathrm{bB}}$ & $0.80^{\mathrm{bB}}$ & $45.53^{\text {a } \mathrm{A}}$ \\
\hline Cylicostephanus calicatus & $14.13^{\text {a АB }}$ & $2.07^{\mathrm{bB}}$ & $23.33^{\text {a } \mathrm{A}}$ \\
\hline Cylicocyclus ashworti & $31.00^{\mathrm{aA}}$ & $2.40^{\mathrm{bB}}$ & $3.13^{\mathrm{bB}}$ \\
\hline Cyathostomum pateratum & $13.43^{\mathrm{aA}}$ & $5.14^{\mathrm{b} \mathrm{AB}}$ & $2.00^{\mathrm{bA}}$ \\
\hline Cylicocyclus leptostomum & $8.87^{\mathrm{aA}}$ & $0.67^{\mathrm{bA}}$ & $2.73^{\mathrm{ab} A}$ \\
\hline Cylicostephanus minutus & $8.27^{\mathrm{aA}}$ & $1.07^{\mathrm{bB}}$ & $0.80^{\mathrm{bB}}$ \\
\hline
\end{tabular}

Means within lines with different letters are singnificantly different $(* \mathrm{P}<0.05, * * \mathrm{P}<0.01)$.

Ciência Rural, v.38, n.8, nov, 2008. 
certain location within the intestine, the occurrence in the three compartments is commonly recorded, which can be explained by seasonality (OUGBOURNE, 1976) and the phase of development of the parasites (OUGBOURNE, 1976; FOSTER, 1936), which could occur anywhere in the intestine, with later migration of newly hatched adults to their favourite habitat (FOSTER, 1936). In spite of the fact that this is subject to speculation, biochemical and nutritional conditions are other factos which, according to OGBOURNE (1976), would explain the preference for certain locations in the intestine, as also the co-existence of several different species as parasites on the same host.

The population of Cyathostminea, from what we have been able to see, remains stable, with similar ecological indicators regardless of the time of year or the geographical location from where the samples were taken. The advent of powerful endectocides with wide spectrum of action, which entered the market in the 1980s, does not seem to have had much influence on the population of Cyathostominea, which, according to BOXELL (2004), happened with large strongylids.

\section{BIOETHICS AND BIOSSECURITY COMMITTEE APPROVAL}

The authors state that the studies with animals were conducted in accordance with ethical standards.

\section{REFERENCES}

ANJOS, D.H.S.; RODRIGUES, M.L.A. Diversity of the infracommunities of strongylid nematodes in the ventral colon of Equus caballus from Rio de Janeiro state, Brazil. Veterinary Parasitology, n.136, p.251-257, 2006.

BARBOSA, O.F. Estudo dos Ciatostomíneos (Strongylidae, Cyathostominae) parasitos de eqüinos (Equus caballus) da região de Jaboticabal, São Paulo, Brasil. 1995. $57 \mathrm{f}$. Dissertação (Mestrado em Zootecnia) - Curso de Pós-graduação em Zootecnia, Universidade Estadual Paulista.

BORGSTEEDE, F.H.M. et al. Benzimidazole resistance in cyathostomes in horses in the Ukraine. Veterinary Parasitology, v.68, p.113-117, 1997.

BOXELL, A.C. et al. Occurence of gastrointestinal parasites in horses in metropolitan Perth, Westhern Australia. Australian Veterinary Journal, v.82, p.91-95, 2004.

BUSH, A.O. et al. Parasitology meets ecology on its own terms: Margolis et al. revisited. Journal of Parasitology, v.83, p.575-583, 1997.

CARVALHO, R.O. et al. Nematodes Cyathostominae parasites of Equus caballus in the state of Minas Gerais. Revista Brasileira de Parasitologia Veterinária, v.7, n.2, p.165168, 1998.
COLLOBERT-LAUGIER, C. et al. Prevalence, abundance and site distribution of equine small strongyle in Normandy, France. Veterinary Parasitology, v.110, p.77-83, 2002.

FOSTER, A.O. A quantitative study of nematodes from a selected group of equines in Panama. Journal of Parasitology, v.22, p.479-510, 1936.

FOSTER, A.O.; ORTIZ O. A further report on the parasites of a selected group of equines in Panamá. Journal of Parasitology, v.23, p.360-364, 1937.

A relationship in equines between age of host and number of Strongylid parasites. American Journal of Hygiene, v.25, p.66-75, 1937.

GEORGI, J.R. Parasitologia veterinária. Rio de Janeiro: Interamericana, 1982. 353p.

HERD, R.P.; COLLES, G.C. Slowing the spread of anthelmintic resistance nematodes of horse in the United Kingdom. Veterinary Record, v.136, p.481-485, 1995.

JAYARAMAN, K. A statistical manual for forestry research. Capturado em 18 jan. 2008. Online. Disponível na Internet: http://www.fao.org./DOCREP/ 003//X6831E00.HTM

LANFREDI, R.M. Estudo dos Ciatostomíneos parasitos de cavalos (Equus caballus, L. 1758) no Município de Itaguaí, R.J. (NEMATODA, STRONGYLIDAE, CYATHOSTOMINAE). 1983. 116f. Tese (Doutorado em Parasitologia Veterinária) Curso de Pós-graduação em Parasitologia Animal. Universidade Federal Rural do Rio de Janeiro.

Le ROUX. P.L. Helminths collected from equines in Edinburgh and in London. Journal of Helminthology, v.2, p.111-134, 1924.

LICHTENFELS, J.R. et al. An annoted checklist by genus and species of 93 species level names for 51 recognised species of small strongyles (Nematoda: Strongylidae: Cyathostominae) of horses, asses and zebras of the world. Veterinary Parasitology, v.79, p. 65-79, 1998.

LICHTENFELS, J.R. et al. Recommended and terminology and advances in the systematic of the Cyathostominae (Nematoda: Strongylidae) of horses. Veterinary Parasitology, v.107, p.337-342, 2002.

LICHTENFELS, J.R. Helminths of domestic equids. Illustrated keys to genera an species with emphasis on North America forms. Proceeding of the Helmintological Society of Washington, v.42, p 1-92, 1975.

LUDWIG, J.A.; REYNOLDS, J.F. Statistical ecology: a primer on methods and computing. New York: Wiley Interscience, 1988. 337p.

MAIR, T.S. et al. Diarrhoea in adults horses: a survey of clinical cases and assessment of some prognostic indices. Veterinary Record, v.126, p.479-481, 1994.

MARGOLIS, L. et al. The use of ecological terms in parasitology (report of an ad hoc Committee of the American Society of Parasitologists). Journal of Parasitology, v.68, p.131-133, 1982. 
NILSSON, O. et al. A filded evaluation of anthelmintics in horses inSweden. Veterinary Parasitology, n.32, p.163-171, 1989.

OGBOURNE, C.P. The prevalence, relative abundance and site distribution of nematodes of the subfamily Cyathostominae in horses killed in Britain. Journal of Helminthology, v.50, p.203-214, 1976.

OLIVEIRA, C.L. et al. Cyathostominae parasites to Equus asinus in some Brazilian States. Arquivo Brasileiro de Medicina Veterinária e Zootecnia, v.46, p.51-63, 1994.

PEREIRA, J.R.; VIANNA, S.S.S. Gastrointestinal parasitic worms in equines in the Paraíba Valley, State of São Paulo, Brazil. Veterinary Parasitology, v.140, p.289-295, 2006.

RODRIGUES, M.L.A. et al. Diversidade das infracomunidades de estrongilídeos, do cólon dorsal de Equus caballus do estado do Rio de Janeiro. Brasil. Parasitología Al Dia, v.24, p.9296, 2000.

RODRIGUES, W.C. Ecologia geral: riqueza e diversidade das espécies. Capturado em 18 jan. 2008. Online. Disponível na Internet: http://www.ebras.bio.br/autor/aulas/.pdf
SHAW, D.J.; DOBSON, A.P. Patterns of macroparasites abundance and aggregation in wildlife populations: a quantitative review. Parasitology, v.111, p.111-113, 1995.

SILVA, A.V.M. et al. Cyathostominae (Nematoda) parasites of Equus caballus in some Brasilian States. Veterinary Parasitology, v.46, p.15-21, 1999.

SOUTO-MAIOR, M.P. et al. Estrutura das infracomunidades de nematóides estrongilídeos (Nematoda: Strongylidae) do ceco de Equus caballus naturalmente infectados, provenientes da Região Metropolitana do Rio de Janeiro, Brasil. Parasitología Al Dia, v.23, p.24-32, 1999.

VAN LOON, G. et al. Larval cyathostomiasis as a cause in two regularly dewormed horses. Journal of Veterinary Medicine, v.42, p.301-306, 1995.

VIANNA, S.S.S.; ARAUJO FILHO, R.S. Identificação das espécies de pequenos estrongilídeos (Nematoda: Cyathostominae) parasitos de muares, na região do Vale do Paraíba, Estado de São Paulo, Brasil. Arquivos do Instituto Biológico, v.56, p.64, 1989.

VIANNA, S.S.S. et al. Identificação dos gêneros e espécies de pequenos estrongilídeos (Nematoda: Cyathostominae) parasitos de cavalos, na região do Vale do Paraíba, Estado de São Paulo, Brasil. Arquivos do Instituto Biológico, v.55, p.29, 1988. 